Al-Bidayah : jurnal pendidikan dasar Islam

Volume 13, Number 1, June 2021

ISSN: 2549-3388 (online)

Available online at https://jurnal.albidayah.id

Submitted: January 16, 2021, Accepted: June 29, 2021

\title{
NON-VIOLENT ISLAMIC ELEMENTARY SCHOOL: CHILD-FRIENDLY SCHOOLS IN INCLUSIVE CLASSES DURING THE COVID PANDEMIC
}

\author{
Sarah Mustika Barokah ${ }^{1}$, Muhammad Nur Wangid ${ }^{2}$ \\ State University of Yogyakarta, Indonesia ${ }^{1,2}$ \\ E-mail: sarahmustika.2019@uny.ac.id ${ }^{1}$, m_nurwangid@uny.ac.id ${ }^{2}$
}

DOI: 10.14421/al-bidayah.v13i1.606

\begin{abstract}
The rise of child abuse cases in Indonesia has demanded the school to implement an anti-violence policy. Thus, the inclusion school of MI Amanah has implemented an anti-violence policy as an implementation form of the Child-Friendly School program. The objective of this research was to describe the implementation of the anti-violence policy during the learning process in the inclusion class as an embodiment of a child-friendly school in MI Amanah, Malang District. This research exerted a qualitative approach; the research data were collected through interviews, observation, and documentation; the data were then analyzed qualitatively and descriptively. The research location was at MI Amanah, Turen Subdistrict, Malang District. The research was conducted from August to December 2020 by employing the foundation's president, principal, and teachers as the research subjects. The research finding indicated that implementing an anti-violence policy in student learning was covered in planning, implementation, and assessment. The learning planning was conducted by designing and organizing the learning materials without ignoring the child specificity; also allocating play, time, and rest. The learning implementation was to use polite greetings, put forward a psychological approach and positive discipline, make study groups in the inclusion class, care for students when they got through learning difficulties, raise tolerance environment, and provide worship and sleeping time. The learning assessment was done objectively by featuring authentic assessment; the assessment should be employed without comparing; the assessment regards the student's potential and skill.
\end{abstract}

\section{Keywords: anti-violence; child-friendly school; inclusive education; Islamic elementary school}

\section{INTRODUCTION}

School is an educational facility for children with an obligation to protect the children and fulfill their rights to grow, live, bloom, and participate optimally according to human dignity and protection from violence and discrimination. This statement is in line with article 28B (2) ${ }^{1}$, which asserts that "Every child deserves survival, growth, and development as well as the protection from violence and discrimination". The violence is again emphasized in article $54^{2}$, which states that "The children within and in the educational unit environment must have protection from any physical and psychic

\footnotetext{
${ }^{1}$ People's Consultative Assembly of the Republic of Indonesia, "The 1945 Constitution of the Republic of Indonesia in One Script" (Secretariat General of the People's Consultative Assembly of the Republic of Indonesia, 1945).

${ }^{2}$ President of the Republic of Indonesia, "Law of the Republic of Indonesia Number 35 of 2014 Concerning Amendments to Law Number 23 of 2002 Concerning Child Protection" (State Secretariat of the Republic of Indonesia, 2014).
} 
violence acts, sexual abuse, and other forms of violence performed by the teacher, educational staff, fellow students, and or other parties". Therefore, every child has the right to get an education without the act of violence.

Child abuse is covered to all kinds of physical and or emotional persecution, sexual abuse, neglect, or exploitation of children under 18 years old, which may cause either actual or potential loss of children health, survival, growth, or dignity in the relationship context between responsibility, trust, or authority ${ }^{3}$. Laws No.35 of 2014 about child ${ }^{4}$ protection has defined that abuse or violence is referred to the actions against the children which can cause forms of suffering (physical, psychic, sexual, or neglect), including a threat to commit a particular act, coercion, or deprivation of child liberty unlawfully. In the educational field, child abuse is triggered by several factors ${ }^{5}$ as (a) punishment, especially physical punishment which is beyond the limit or not according to the violation condition, so it raises to the violence; (b) curriculum content which put asides humanization and prioritizes cognitive aspect; (c) the violence which is occurred because of reflection from the development of community life which has undergone a rapid shift, so it necessitates the rise of shortcut manner; (d) the effect from the doer's socio-economic background. Meanwhile, in the process of learning, there are at least two triggers of student abuse ${ }^{6}$. Firstly, the trigger from the teacher. The action or behavior triggered by the teacher is usually and formerly planned. Secondly, the external trigger is student attitude. The behavior triggered by student attitude is typically creative, so it is not formerly planned because student behavior is contextual.

Child abuse consists of four types: emotional abuse, physical abuse, sexual abuse, and neglect ${ }^{7}$. Emotional abuse does not implicate physical or sexual abuse. However, it can still impact uncomfortable feelings and depression, hampering the child's emotional

\footnotetext{
${ }^{3}$ Müdriye Yildiz Biçakçi, Sühendan Er, and Neriman Aral, "An Overview of Child Neglect and Abuse: Types, Causes, Impact and Prevention," Studies on Ethno-Medicine 10, no. 2 (2016): 221-28, https://doi.org/10.1080/09735070.2016.11905491.

${ }^{4}$ President of the Republic of Indonesia, "Law of the Republic of Indonesia Number 35 of 2014 Concerning Amendments to Law Number 23 of 2002 Concerning Child Protection," (State Secretariat of the Republic of Indonesia, 2014).

${ }^{5}$ Hamsatu Joseph Pur, Mukhtar Alhaji Liman, and Domiya G. Ali, "Students' Perception of Causes and Effect of Teachers' Psychological Abuse in Senior Secondary Schools in Borno State, Nigeria," Journal of Education and Practice 7, no. 29 (2016): 111-19, https://eric.ed.gov/?id=EJ1118806.

6 Sylvia Lungile Dlamini and Davison Makondo, "Effects of Child Abuse on the Academic Performance of Primary School Learners in the Manzini Region, Swaziland," World Journal of Education 7, no. 5 (2017): 58, https://doi.org/10.5430/wje.v7n5p58.

7 Rodrick Babakhanlou \& Tom Beattie, "Child Abuse," Innovait, 2019, https://doi.org/10.1001/jama.285.10.1360-JBK0314-3-1.
} 
development and harming its personality. The emotional abuse which occurs in an educational field is related to verbal and non-verbal actions. The verbal action is like using satire, mockery, humiliating statements, yelling, naming, offending, mocking the student's appearance or disability, and negative comments about the child's family.

Meanwhile, non-verbal action includes ignoring the student, for instance, giving home assignments to apply discipline and exert punishment if the student does not answer correctly $^{8}$. Physical abuse is referred to as a behavior performed intentionally or unintentionally to injure physically, so it causes bruising, scratch, burn, fracture, tear, recurring accident, and harsh treatment, which can impact physical injury ${ }^{9}$. Sexual abuse is a sexual activity as a form of intimidation or threat, either physically or verbally ${ }^{10}$. Neglect is more commonly found in children. Neglect is defined as a constant failure of a caregiver to fulfill children's physical, emotional, educational, and medical needs, impacting the growth delay or physical and psychological harm. ${ }^{11}$ The child is the most vulnerable object to violence or abuse because they are helpless and filled with fear towards threat and coercion.

The data of the Indonesian Children Protection Commission ${ }^{12}$ has recorded the abuse cases on children from January to June 2020 is approximately 3.087, particularly 852 cases of physical abuse, 768 cases of psychic abuse, and 1.848 cases of sexual abuse. In June 2020, two children with special needs lived in Jakarta and were left by their parents because of underprivileged economic conditions to support daily life needs. Moreover, those two children did not obtain educational services because they were

${ }^{8}$ Finiki Nearchou, "Resilience Following Emotional Abuse by Teachers: Insights from a CrossSectional Study with Greek Students," Child Abuse and Neglect 78, no. May 2017 (2018): 96-106, https://doi.org/10.1016/j.chiabu.2017.10.012.

9 D. Theoklitou, N. Kabitsis, and A. Kabitsi, "Physical and Emotional Abuse of Primary School Children by Teachers," Child Abuse and Neglect 36, no. 1 (2012): 64-70, https://doi.org/10.1016/j.chiabu.2011.05.007.

${ }^{10}$ Erhamwilda Erhamwilda and Nurul Afrianti, "Analysis on Early Childhood Sexual Abuse and the Implications in Islamic Education," Jurnal Pendidikan Islam 2, no. 1 (2016): 105, https://doi.org/10.15575/jpi.v2i1.696.

${ }^{11}$ Monica Lawson, Megan H. Piel, and Michaela Simon, "Child Maltreatment during the COVID19 Pandemic: Consequences of Parental Job Loss on Psychological and Physical Abuse Towards Children," Child Abuse and Neglect, no. July (2020): 104709, https://doi.org/10.1016/j.chiabu.2020.104709.

12 Kementerian Pemberdayaan Perempuan dan Anak Perlindungan, "Angka Kekerasan Terhadap Anak Tinggi Di Masa Pandemi, Kemen PPPA Sosialisasikan Protokol Perlindungan Anak," 2020, https://www.kemenpppa.go.id/index.php/page/read/29/2738/angka-kekerasan-terhadap-anak-tinggi-dimasa-pandemi-kemen-pppa-sosialisasikan-protokol-perlindungan-anak. 
rejected from entering inclusive schools for health reasons ${ }^{13}$. This condition is contradicted to the Regulation of the Ministry of National Education of the Republic of Indonesia No.70 of $2009^{14}$, which has stated that every student who has physical, emotional, mental, social abnormalities, or potential intelligence and or special sense is deserved to attend inclusive education in specific educational units according to the student need and ability. Thus, the children with special needs should have the same opportunity to get their educational rights either through inclusive education or special education school without having any abuses.

The children abuse requires the school to implement an anti-violence policy because this policy will affect the children ${ }^{15}$. The children's growth and development, which experiences violence, are commonly different from the normal children. The direct impacts of child abuse are mortality (5\%), serious complication as disability, fracture, and bruise $(25 \%)$. The indirect effects on children can cause permanent harm to the nervous system to cause mental retardation, learning problem, motor development problem, seizure, ataxia, and hydrocephalus ${ }^{16}$. If child abuse in school is not stopped, it will impact the child's growth and development, affecting future human resource quality. Hence, the Ministry of Education and Culture has appealed to all schools implementing a Childfriendly School program to embody a safe, comfortable, healthy, friendly, and fun school for children.

The child-friendly school is motivated by the educational process, which still regards the child as an object. At the same time, the teacher is a party who is always right; therefore, it can quickly generate abuse incidents in the school. The child-friendly school is a program that aims to realize the safe, clean, healthy condition, caring attitude, and environmental culture that can give rights and protect children from abuse, discrimination, and other types of deviant behaviors as long as they are in the education

13 Tim KPAI, "Miris! Dua Anak Disabilitas Ditelantarkan, Ditolak Sekolah Inklusi Hingga Dikunjungi KPAI," 2020, https:/www.kpai.go.id/berita/miris-dua-anak-disabilitas-ditelantarkan-ditolaksekolah-inklusi-hingga-dikunjungi-kpai.

${ }^{14}$ Minister of National Education Republic of Indonesia, "Regulation of the Minister of National Education of the Republic of Indonesia Number 70 of 2009 Concerning Inclusive Education for Students Who Have Abnormalities and Have Potential Intelligence and/or Special Talents" (Ministry of National Education Republic of Indonesia, 2009).

${ }^{15}$ Nearchou, "Resilience Following Emotional Abuse by Teachers: Insights from a Cross-Sectional Study with Greek Students."

${ }^{16}$ Dyah Indraswati et al., "Implementasi Sekolah Ramah Anak Dan Keluarga Di Sdn 2 Hegarsari, Sdn Kaligintung, Dan Sdn 1 Sangkawana," JKKP (Jurnal Kesejahteraan Keluarga Dan Pendidikan) 7, no. 01 (2020): 51-62, https://doi.org/10.21009/jkkp.071.05. 
units $^{17}$. Moreover, this child-friendly school aims to create a positive environment for the children by giving support, preventing bullying acts or neglect, both the teacher and facilitator supporting and concerning for each other; the school is more focusing on student specialty than their deficiency and creating the inclusive environment which can accommodate all children ${ }^{18}$.

The inclusive school should provide accessible educational services to all students, either with disabilities, low economy, or other kinds of limitations ${ }^{19}$. As one of the forms of implementing child-friendly inclusive schools, the school can create inclusive learning, especially for the students with special needs. The learning implementation in an inclusion class is not apart from the role of the teacher ${ }^{20}$. Salahudin has explained that the teacher is a vital element to create the child-friendly inclusion class by developing the science and skill to achieve learning success in the child-friendly inclusive learning environment by welcoming, taking care of, educating all children without seeing their gender, physical, intellectual, social, emotional state, language, or other characteristics ${ }^{21}$.

Leino $^{22}$ has argued with another opinion that is based on his research finding on child-friendly inclusive schools. He stated that the children with special needs in their learning need greater discipline than the other normal children. This greater discipline is used as one of the therapies since children with special needs require more intensive supervision than children with no special needs. Moreover, he has also said that education for sustainable human resource development does not have to implement the concept of

17 State Minister for Child Empowerment and Protection of the Republic of Indonesia, "State Minister for Women's Empowerment and Child Protection of the Republic of Indonesia, "Regulation of the State Minister for Child Empowerment and Protection of the Republic of Indonesia Number 8 of 2014 Concerning Child Friendly School Policies" (State Ministry for Child Empowerment and Protection of the Republic of Indonesia, 2014).

${ }^{18}$ P. Aneesh Kumar Shinto Thomas, K. Alphonsa Jose, Positive Schooling and Child Development: International Perspectives, Positive Schooling and Child Development: International Perspectives (Springer Singapore, 2018), https://doi.org/10.1007/978-981-13-0077-6.

${ }^{19}$ Mireille Krischler, Justin J.W. Powell, and Ineke M. Pit-Ten Cate, "What Is Meant by Inclusion? On the Effects of Different Definitions on Attitudes toward Inclusive Education," European Journal of Special Needs Education 34, no. 5 (2019): 632-48, https://doi.org/10.1080/08856257.2019.1580837.

${ }^{20}$ Admila Rosada, "The Effectivity Of Empathic Love Therapy To Increase Subjective Well-Being And Teacher Readiness In Inclusive School," Al-Bidayah: Jurnal Pendidikan Dasar Islam 11, no. 2 (2020): 248-63, https://doi.org/10.14421/al-bidayah.v11i2.282.

${ }^{21}$ Siddiqui Fakeha Salahuddin, "Building Inclusive Learning Friendly Classrooms: Need of the Hour," International Journal of Reflective Research in Social Sciences 1, no. 1 (2017): 10-13, https://www.reflectivejournals.com/download/4/1-1-4.pdf.

${ }^{22}$ Mare Leino, "The Child Friendly School: An Idea Versus Reality," Problems of Education in the 21 st Century 29 (2011): 82, http://www.scientiasocialis.lt/pec/files/pdf/vol29/82-88.Leino_Vol.29.pdf. 
a friendly school. He has borrowed a term old-fashioned school with fairly harsh supervisory characteristics from the outside, but there is well found inside. The research gap found between Leino and Salahudin on inclusive learning in the class is due to the difference of comprehension factor and teacher readiness to the child-friendly inclusive education, which then affects the handling of student need in the class. Further, the discipline in learning is not followed by any physical and verbal violence. Still, it will lead to the abuse act when followed by physical and verbal punishment and aggressive attitude. Therefore, this discussion aims to describe the implementation of the antiviolence policy of child-friendly schools during the learning process, including planning, performance, and evaluation.

MI Amanah is an inclusive school located in Southern Malang. Several students are from the other sub-districts, which is the nearest, about $20 \mathrm{~km}$. MI Amanah is a school that implements a child-friendly school (CFS) program with the inclusive school concept. The commitment of MI Amanah to declare the child-friendly school with anti-violence has become a challenge when the learning involves regular students and students with special needs. MI Amanah has adopted Havighurst's task development to practice inclusive education as a form of child-friendly school implementation through antiviolence policy. Therefore, this research aims to identify child-friendly schools' performance through anti-violence policy in MI Amanah inclusive school.

\section{RESEARCH METHODS}

This research exerted a qualitative approach, which was aimed to identify the phenomena experienced by the research subjects. The techniques of data collection were interviews, observation, and documentation. The researcher acts as a critical instrument in interview activities, collecting data, and knowing the field conditions to obtain in-depth and comprehensive data about learning at MI Amanah, including the planning, implementation, and evaluation stages. Observations were made by collecting empirical facts on the implementation of child-friendly inclusive schools at MI Amanah. Documentation is carried out to obtain information in books, archives, curriculum documents, syllabus, lesson plans, and pictures related to implementing child-friendly school learning in inclusive classes. The research location was in MI Amanah inclusive school, Turen Sub-district, Malang District. The research was conducted from August to December 2020. 
The data collected in this research were related to implementing child-friendly schools through anti-violence policy in the learning practice, comprised of planning, implementation, and evaluation. The data sources in this research were obtained through interview techniques with several informants as head of the foundation, principal, three classroom teachers, and three children with special needs. The researchers employed an in-depth interview. The other data sources in this research were obtained through observation and documents relating to implementing the anti-violence policy of the childfriendly school in MI Amanah inclusive school. The data analysis exerted data collection, data reduction, data display, and conclusion.

\section{RESULT AND DISCUSSION}

Inclusive education in school was an attempt at educational equalization for students with special needs. The inclusive madrasah has more advantages than the regular inclusive school because the education in madrasah taught to appreciate and offer an opportunity to the students based on devotion to Allah SWT ${ }^{23}$. As an inclusive madrasah, MI Amanah accepted all students who wanted to go to school without setting specific criteria. The students with special needs in MI Amanah consisted of nineteen students in the $1^{\text {st }}-6^{\text {th }}$ grade of the elementary school in the school year of $2019 / 2020$. The specialties of students with special needs in MI Amanah were comprised of autism, speech delay, low vision, deaf, physically disabled, children with learning difficulties, motor impairment, and talented children. The majority of students who have been accepted in MI Amanah were the children who were rejected by the other schools in consideration of student limitation or school unpreparedness factor to prepare to learn for the students with special needs. Before entering the inclusion class, the students with special needs in MI Amanah would have preliminary service in a transition class comprised of three teachers and a specific learning time duration adjusted to the student readiness. Then, the students with special needs would enter the inclusion class based on independence, social, and skill.

${ }^{23}$ Sulthon Sulthon, "Model Pelayanan Pendidikan Inklusi Di Madrasah: Studi Kasus Di Madrasah Ibtidaiyah Ibtidaul Falah Dawe-Kudus," Al-Bidayah: Jurnal Pendidikan Dasar Islam 10, no. 2 (2019): 151-72, https://doi.org/10.14421/al-bidayah.v10i2.161. 
The presence of child-friendly school established in the regulation of Women Empowerment and Child Protection Ministry $8^{\text {th }}$ in $2014^{24}$, MI Amanah was an inclusive madrasah has to implement some efforts to realize anti-violence school. The indicators of child-friendly school were planning, implementation, and evaluation. The learning process in MI Amanah was based on the Havighurst development task. According to Havighurst $^{25}$, the development task on children of 6-12 years old including the following points: (a) to learn acquiring physical skills for playing games; (b) to learn socializing with peers; (c) to learn playing a role according to the gender; (d) to learn basic skills of reading, writing, and counting; (e) to learn developing daily concepts; (f) to develop inner voice; (g) to learn acquiring personal freedom; (h) to develop positive behavior to the group. The development task in the learning process would be adjusted to each student's skill and interest to develop according to their stages and no curriculum load. The learning curriculum used in the MI Amanah inclusion class was the 2013 curriculum.

The followings were the school efforts to realize a child-friendly school with an anti-violence policy in MI Amanah during the learning process:

\section{Learning Planning}

The learning planning designed by MI Amanah was based on the inclusive program in the curriculum document of inclusive madrasah. The learning would not be apart from the inclusive program declared within the curriculum in MI Amanah. The following inclusion class programs were used as references to planning the learning: (a) to be able to accommodate the community who want a qualified inclusive madrasah due to the community needs; (b) to prepare a specific room of inclusion class which suits to the learning need and facility; (c) to fulfill the educational game tools, specifically in the inclusion class of MI Amanah which fit the student ability and development; (d) to prepare a shadow teacher for students with special needs who should be equipped with the knowledge of how to handle the students with special needs by following training of handling the students with special needs.

${ }^{24}$ State Minister for Child Empowerment and Protection of the Republic of Indonesia, "State Minister for Women's Empowerment and Child Protection of the Republic of Indonesia, "Regulation of the State Minister for Child Empowerment and Protection of the Republic of Indonesia Number 8 of 2014 Concerning Child Friendly School Policies."

25 Robert J. Havighurst, Raymond G. Kuhlen, and Carson Mcguire, "Chapter IV: Personality Development," Review of Educational Research 17, no. 5 (1947): 333-44, https://doi.org/10.3102/00346543017005333. 
The teacher should design the lesson by creating a comfortable learning atmosphere and conducive class environment for the students with special needs or the other one. The lesson planning made by the teachers in MI Amanah related to the mandatory learning administration was covered to the academic calendar, annual program, a semester program, minimum completeness criteria, syllabus, lesson plan, and module, which were expected to direct the teacher to plan the lesson by accommodating each student need in the inclusion class. Next, the lesson plan document in this research was referred to the lesson plan and syllabus. The lesson plan and syllabus were the learning administration that must be arranged based on curriculum reference. Based on the inclusive program curriculum of MI Amanah, the development of the learning or lesson plan was adjusted to the student's needs and abilities. The research findings showed that the teachers in MI Amanah had developed the syllabus and lesson plan aimed at fun learning, no compulsion, no stress or anxiety on students, and student needs.

The seating organization without the chair and use of folding table was the specific characteristic of MI Amanah to draw the closer psychological distance. The seating arrangement aimed to accommodate all student needs without being limited by chair arrangement and lessen the gap between teacher and student. The learning setting by sitting together without being defined by benches and chairs would juxtapose psychological distance between the teacher and students or among the students. Drawing a close psychological distance between them would prevent discrimination to the students with special needs that the teacher-student or among the students might perform.

The teachers in MI Amanah have arranged the lesson plan and syllabus by organizing the lesson material without neglecting the student's specialty. The materials were adjusted to the student need, and also, the indicators making was more derived from the students with special needs who were less cognitive. In contrast, the materials would be developed more quickly on the students with special needs who have superiority in mental skill by offering acceleration program in $2^{\text {nd }}$ and $3^{\text {rd }}$ grade of elementary school within one school year to graduate faster.

The teachers in MI Amanah have planned the learning module that was adjusted to each student's need and ability that required creativity to generate meaningful and fun learning. The result of the interview and documentation showed that the inherent characteristic in MI Amanah to arrange the learning was no use of student worksheets 
which the government distributed. Still, the teacher set their lesson module. The lesson module designed by the teacher has consisted of: (a) the opening (module title, table of contents, competency goal), (b) the core (material description, learning activity, formative test, assignment, and summary); (c) the closing (final test). A planned lesson module could help the student individually achieving their learning goals, so the students who have a high learning speed would be quicker to master the lesson materials. In contrast, the students who have a low learning speed could learn again by repeating and reviewing the part that has not been understood yet $^{26}$. Furthermore, MI Amanah commits the inclusive madrasah that used learning or lesson module as non-discriminatory teaching material to students' intelligential, physical, and emotional state and more developed the student potential or each characteristic.

As an inclusive madrasah, MI Amanah has focused on the learning needs, rest, playtime, worship, and relaxation in the learning plan arrangement. Besides the need for learning, the student also needed rest and playtime with peers to develop their emotional, social attitudes. MI Amanah has allocated the time for students to perform zuhr and asr prayers. Zuhr is an obligatory prayer of four raka'at from noon until late in the evening. Asar is one of the obligatory prayers of four raka'at performed after the length of the shadow of an object is equal to the height of the thing until before sunset. Because MI Amanah has allocated time for students to perform zuhr and asr, they could perform worship obligations as Muslims and get closer to Allah SWT. The relaxation was a vital part of the lesson plan because it allowed students to rest their brains and avoid continuous learning ${ }^{27}$. Based on the research data, this research found that the relaxation time in MI Amanah lasted for an hour, it was from 12.30 to 1.30 PM. The relaxation was filled with nap time so that the students could have enough rest time. The students' adequate sleep time could help them increase cognitive performance, academic achievement, and physical and health maintenance ${ }^{28}$. MI Amanah has also provided a sufficient relaxation time for the students, which was aimed to maintain their physical and mental health.

${ }^{26}$ Sukiman, Pengembangan Media Pembelajaran (Yogyakarta: Pustaka Insan Madani, 2011).

${ }^{27}$ Rezaei Kargar Flor et al., "Effect of Relaxation Training on Working Memory Capacity and Academic Achievement in Adolescents," Procedia - Social and Behavioral Sciences 82 (2013): 608-13, https://doi.org/10.1016/j.sbspro.2013.06.318.

${ }^{28}$ Sing Chen Yeo et al., "Associations of Time Spent on Homework or Studying with Nocturnal Sleep Behavior and Depression Symptoms in Adolescents from Singapore," Sleep Health 6, no. 6 (2020): 758-66, https://doi.org/10.1016/j.sleh.2020.04.011. 
Those considerations were in line with the regulation of the Ministry of Women Empowerment and Children Protection of the Republic Indonesia No.8 of 2014 concerning the policy of the child-friendly school, which has clearly stated that the childfriendly school in the learning process should offer the opportunity for students to get involved in activities such as playing, exercising, and resting ${ }^{29}$.

\section{Learning Implementation}

The learning interaction employed respectful communication for each other, which was shown by selecting polite greetings. The specific characteristic that appeared during the learning process at MI Amanah was through the interaction between teacher and students, which called "mas" (brother Eng.) to the male students, and "mbak" (sister $\sim$ Eng.) for the female students, and these calls were applied for either the normal students or students with special needs. Likewise, the students would call one another by calling "mas" and "mbak" to either the junior or senior peers. The use of polite greetings to the students was one of the mutual concern forms, so the students would not feel neglected and prevent verbal abuse behavior ${ }^{30}$. All this time, the teacher was focused on the cognitive result, so the teacher tended to ignore the student's needs to feel more appreciated and build effective communication within the learning process ${ }^{31}$. In Islamic education, polite greetings provide more opportunities for the students to gain bonds of love and affection by prioritizing togetherness, interaction, and creativity with peers and supporting the teacher to create a contented and harmonious relationship amid disparity with no abuse ${ }^{32}$.

The teacher's behavior to educate the students was performed based on tabayun by implementing a positive discipline and psychological approach without physical, verbal, or sexual abuse and neglect. Tabayun is selecting information or news by checking

29 State Minister for Child Empowerment and Protection of the Republic of Indonesia, "State Minister for Women's Empowerment and Child Protection of the Republic of Indonesia, "Regulation of the State Minister for Child Empowerment and Protection of the Republic of Indonesia Number 8 of 2014 Concerning Child Friendly School Policies."

${ }^{30}$ Ribut Wahyu Eriyanti, "Power Gap as One of the Trigger of Verbal Abuses Committed by Teachers in Schools," International Journal of Instruction 11, no. 1 (2018): 363-78, https://doi.org/10.12973/iji.2018.11125a.

${ }^{31}$ Emily Lai, Kristen DiCerbo, and Peter Foltz, Skills for Today: What We Know about Teaching and Assessing Collaboration, Pearson (Pearson, 2017), https://eric.ed.gov/?id=ED576950.

32 Ahmad Tarmizi Hasibuan and Rahmawati Rahmawati, "Sekolah Ramah Anak Era Revolusi Industri 4.0 Di SD Muhammadiyah Pajangan 2 Berbah Yogyakarta," Al-Bidayah: Jurnal Pendidikan Dasar Islam 11, no. 01 (2019): 49-76, https://doi.org/10.14421/al-bidayah.v11i01.180. 
and rechecking, verifying, and seeking the truth of the data. If a student persistently violated the rule, the teacher would do tabayun to seek the truth regarding the problem source. The problem factor could have appeared from the teacher, student, parent, or other people. The teacher should use positive utterances to change the negative behavior of the student. One of teachers who taught students with special needs in an inclusion class told a story when he admonished a student with special needs in his class by approaching the student and saying, "Hi, kid! You are a good student! However, it would be great if you listen to the teacher's explanation". The teacher's saying was expressed without exceeding the relation between teacher and student, which could rise to sexual contact. The positive disciplinary behavior was based on the interview and observation; the teacher did not give physical sanction or harsh words to educate the student.

Moreover, the teacher did not ignore when the student violated the rule; the teacher would give the student a disciplinary measure without causing the student's mental or physical injury. The example of student's offense was littering, and in this case, the student would be asked to read istighfar 20 times, and istighfar 100 times while standing for the serious violation. Istighfar is an act of saying astaghfirullah to ask Allah for forgiveness when trying to prevent wrongdoing or asking forgiveness for mistakes. The positive discipline with a psychological approach was a humanistic strategy used by the teacher to settle the student's problems with listening and empathy traits. The teacher would listen to the student's issues, create communication, decide perspective, show empathy and attention, and decide a form of self-discipline. The use of positive discipline would have positive impacts either for regular students or students with special needs ${ }^{33}$. The success of positive discipline in the inclusion class learning needed a huge role of someone to avoid taking a one-way attitude within decision making and position himself as the only one truth while the others were always wrong. Reversely, the teacher became an important key to act tabayyun towards the problems faced by the students either relating to learning difficulty or negative attitude.

The teacher exerted a learning module that was aimed to concern about each student's needs. The selection of appropriate learning modules for the students with

${ }^{33}$ Wen-ling Wang and Chang-yuan Kuo, "Relationships Among Teachers ' Positive Discipline , Students 'Well-Being and Teachers' Effective Teaching: A Study of Special Education Teachers and Adolescent Students With Learning Disabilities in Taiwan Relationships Among Teachers ' Positive Disci," International Journal of Disability, Development and Education, 2018, 1-17, https://doi.org/10.1080/1034912X.2018.1441978. 
different demands because the module contained the smart presentation of certain information $^{34}$. The teacher used a learning module which was consisted of learning material, learning activity, and evaluation. The teacher arranged the module according to the student's needs in the class. The use of the learning module in the class was done classically and then directed to personal guidance on students with special needs who lack comprehension of learning material. The teacher would ask the students about the parts they have not understood yet in the module, so he guided the students learning. The selection of learning modules was accustomed to the need of each teacher to minimize the probability of curriculum load on students because they have to finish the same lesson materials between students with special needs and regular students. The government provided the use of student worksheets in an inclusion class could trigger unexplained learning stress levels felt by the students, which then triggered the teacher to give disciplinary action that led to verbal and physical punishment, or neglect since the students were considered as incapable of learning because of their specialties. As a result, the students got abuse or violence in their education, and child-friendly learning was not completely created. Therefore, since the beginning, MI Amanah has prohibited all teachers from using student worksheets provided by the government in an inclusion class. Still, the madrasah required all teachers to arrange modules that would accommodate each student's need to achieve development tasks and avoid violence.

The group learning in an inclusion class was aimed to make the students could participate together in learning. The teacher would not merely employ the lecture method in chalk and talk in the practice of education, but the teacher would also form study groups. The study group was arranged heterogeneously. Within the study group, the teacher would direct the students to cooperate among the group members and even with special needs. The students should have collaborated to do the group task given by the teacher. The group learning was conducted without ignoring the student's need for selfactualization in either group or individually ${ }^{35}$. Through group learning, the teacher could

34 Jill Friestad-Tate, Carol Schubert, and Craig McCoy, "Understanding Modular Learning-Developing a Strategic Plan to Embrace Change," Journal on School Educational Technology 9, no. 4 (2014): 32-44, https://eric.ed.gov/?id=EJ1097629.

35 Vanessa A. Völlinger and Marina Supanc, "Student Teachers' Attitudes towards Cooperative Learning in Inclusive Education," European Journal of Psychology of Education 35, no. 3 (2020): 727-49, https://doi.org/10.1007/s10212-019-00435-7. 
give more opportunities to the students to learn, arousing curiosity, finding and opening the student's opportunities to state their opinions.

The seating organization without a partition use was a basic measure employed by the teacher in the learning process to juxtapose the psychological distance between the teacher and students or among the students. The student learning organization in MI Amanah was designed without a partition, so it seemed like a hall which we could find some boards inside for learning activities in a class group consisting of 15-20 students. Without partition, the student seat could ease the teacher to keep eye contact and verbal communication with the students, especially the students with special needs, because they tended to have difficulty in concentration and be distracted easily during the class ${ }^{36}$. Furthermore, the teacher should position himself as a caregiver rather than a leader in the class. If the teacher understood the student's condition, it could prevent abuse caused by either the teacher's planned action or the student's spontaneous action.

The students were involved in determining the learning place without any coercion. The learning in an inclusion class was strictly valued as learning in the class and the best place to understand where the students could decide the learning place to develop their self-potential ${ }^{37}$. Also, the students could propose to the teacher whether to use the garden or library as their learning site. The students in MI Amanah were not forced to study in the class, but they could freely decide the comfortable place to learn.

The learning should benefit educative game tools as one of learning media that has fulfilled Indonesia National Standard as a form of therapy for students with special needs and means of playing. The availability of educative game tools in MI Amanah was suitable for the inclusion class program curriculum. Within the learning implementation, the teacher should employ learning media, for instance, an educative game tool that could benefit either the students with special needs or other students. The examples of educative game tools in the school were Cuisenaire block, colors and shapes lotto game, trampoline, gymnastic ball, educative stair, pair card, number symbol card, alphabet card, and finger

${ }^{36} \mathrm{Yi}$ Chen, "Exploring the Role of Communication in Inclusive Education for Children with Learning Disabilities" (2019 International Conference on Advanced Education Research and Modern Teaching (AERMT 2019), Atlantis Press, 2019), 296-98, https://www.atlantispress.com/article/125919501.pdf.

37 Peder Haug and Peder Haug, "Understanding Inclusive Education: Ideals and Reality Understanding Inclusive Education : Ideals and Reality," Scandinavian Journal of Disability Research 0, no. 0 (2017): 1-12, https://doi.org/10.1080/15017419.2016.1224778. 
puppet. The educative game tool was a media of learning that functioned to help the students with special needs optimize their ability. They have impairment or deficiency that limited their selves to access physical or psychic activities. Moreover, the students' educative game tool was utilized with special needs and the regular students as the indoor game.

The assistance for students with special needs in an inclusion class by shadow teacher was required when the students found difficulties in learning, emotional, behavioral, and social disturbance. The students with special needs could learn and study in the inclusion class with a shadow teacher who would help them in their learning difficulties. The presence of a shadow teacher for the students with special needs during the learning difficulty was a form of caring behavior to the student specialty when they got through the problems either in cognitive or socio-emotional aspects.

MI Amanah has raised tolerance among each other to the existence of students with special needs in the inclusion class. The regular student, teacher, and parent should accept students with special needs in the class. This condition was indicated by the teacher's manner, who did not feel disturbed by the presence of students with special needs who wanted to sit next to him to grab attention. Likewise, the other students have good communication with the students with special needs. For instance, when the student with special needs unintentionally forgot and left the bag in the garden, the other students would help bring the bag to the class without feeling any compulsion or bullying.

The students could have rest, playtime, and relaxation based on the schedule. Based on the research result, the data showed that in the daily school activity, the students have rest, playtime, and relaxation in between the learning activities. For the $1^{\text {st }}-3^{\text {rd }}$ grade students, the rest and playtime were at 09.00-09.30. During the break hour, the normal students could socialize with special needs without compulsion and create happiness and fun. The students could also play together with the students with special needs; even if the students with special needs felt sad, the normal students could console them. The $4^{\text {th }}$ $6^{\text {th }}$ grade students have twice break time at 09.00-09.30 and zuhr prayer time at 11.3012.00. After $z u h r$ prayer time, it was continued to lunch at 12.00-12.30 and relaxation at 12.30-13.30 at one time. The relaxation was given by giving nap time in the school hall, class, or other comfortable places. Every student has a pillow with their names on which has been provided by the parent association. The relaxation time was longer than the break 
hour, it was about an hour for the students to take a nap, and they could wake up at 13.30 and continue to recitation. The lack of sleep quality would impact the health disturbance, especially on the students with special needs; they ought to have an adequate break. This situation was reinforced by the student's school schedule, which started from the morning until the afternoon, so the afternoon break was more likely gotten in the school. The lack of nap time in the growth and development phase was a serious risk for students' academic success, health, and safety ${ }^{38}$. The fulfillment of adequate nap time in the school would prevent the students from sleepiness, so it helped them maintaining emotional stability and mood $^{39}$, moreover, on the students with special needs who were vulnerable to tantrum tendencies. Then, MI Amanah did not neglect and ignore the student's cognitive performance, socio-emotional relationship, physical growth, and mental development to develop optimally.

\section{Learning Evaluation}

The evaluation in MI Amanah was done objectively by putting forward an authentic evaluation. The teacher employs the authentic evaluation by collecting information related to the learning development and achievement to prove precisely that the learning goal and basic competence have been mastered. The teacher's authentic evaluation was employed through preparation, work implementation, and work outcome stages. In the preparation stage, the teacher would see how far the students have prepared to do the assignments. In the implementation stage, the teacher would assess the students based on evaluation indicators. Last, on the outcome stage, the teacher would determine the student achievement based on the indicators.

The teacher evaluated learning results without comparing one student to another. The teacher would tend to see each student's potential to be developed. For example, the student with special needs with a high learning outcome in the painting would be facilitated with painting lessons and participating in competitions. he painting work of students with special needs has been displayed in the school to get appreciated well by the school communities or society. Also, the other students who have intelligence levels

\footnotetext{
${ }^{38}$ Jean-Philippe Chaput et al., "Systematic Review Of The Relationships Between Sleep Duration And Health Indicators In School-Aged Children And Youth," Applied Physiology, Nutrition, and Metabolism 41, no. 6 (Suppl. 3) (June 1, 2016): S266-82, https://doi.org/10.1139/apnm-2015-0627.

39 June C. Lo et al., "Cognitive Performance, Sleepiness, and Mood in Partially Sleep Deprived Adolescents: The Need for Sleep Study,” Sleep 39, no. 3 (March 1, 2016): 687-98, https://doi.org/10.5665/sleep.5552.
} 
above the average could finish the learning material faster than the other students; thus, they could finish the study in elementary school in less than six years. The students who entered the acceleration class were recommendations from the teacher in 1st grade; then, the school asked approval from either the parent or student to follow the acceleration program in the 2nd and 3rd grades. The school would not forbid or give sanctions if the parent or student refused to follow the program. The evaluation and assessment in acceleration class were done eight times a year, consisting of four tests for $2^{\text {nd }}$-grade materials and four tests for $3^{\text {rd }}$-grade materials. The test was conducted with fun, so the students would not feel like a burden for them to do the test questions. Thus, the students would not be depressed psychologically and have fun learning with the teacher and peers. On the contrary, the students with special needs who were in the weak cognitive category completed the education in MI Amanah at the earliest seven years, along one year, the students were allocated to a transition class which was evaluated according to independence, social, and skill, and next they could continue the six years in the inclusion class. The difference of study period completion in MI Amanah between regular students and students with special needs was adjusted to the student skill.

The teacher evaluation was not only based on the cognitive aspect but also on student potential and skill. This evaluation would help the students developing their potential and talent other than the academic field. The self-development activity was conducted every Saturday in MI Amanah, which aimed to be a form of school concern to explore the student potential through football, cooking class, dance, painting, and coloring activities. The evaluation agreement in MI Amanah was focused on the academic score and potential, and skill development, which could help the students avoid violence or abuse that might be done during the learning. This decision was based on the fact that the teacher who has only focused on academic score would tend to say "stupid," "lazy," "you cannot do even the simple one," as the emotional abuse on certain students ${ }^{40}$. The violence experienced by students would impact them to have fear during the exam because they might be afraid to get threatened by the teacher if they could not result in a good exam score ${ }^{41}$. Therefore, the learning evaluation could cause violent behavior if it

40 Sinem Şimşek and Fulya Cenkseven-Önder, "An Investigation The Behavioral Problems Of Adolescents, Who Perceived Emotional Abuse From Parents And Teachers," Elementary Education Online 10, no. 3 (2011), https://www.academia.edu/download/26115912/v10s3m24.pdf.

${ }^{41}$ Rukiye Kiziltepe et al., "Prevalence of Violence by Teachers and Its Association to Students' Emotional and Behavioral Problems and School Performance: Findings from Secondary School Students 
was only relied on the cognitive aspect and put aside the affective part, and due to the lack of humanization process in education.

The implementation of learning in child-friendly inclusive schools without violence at MI Amanah is the answer to the difficulties of education practitioners in finding a real picture of child-friendly policies in inclusive schools that provide comfortable learning without presenting violence. The explanation of the learning strategy designed by the school is a system that has been built based on the thoughts and mutual agreement of all parties involved with mutual trust that the school is a trusted institution to provide education with equal principles made from a positive culture of students, teachers, parents, schools, and communities.

\section{CONCLUSION}

The anti-violence education was the right place for children because of their natures of growth and full of happiness. MI Amanah was an inclusive madrasah with an anti-violence policy which has been designed, approved, and implemented by all school communities, including the head of the foundation, school principal, teacher, student, parent, and society who synergistically implemented the policy together by involving regular students and students with special needs in an inclusion class.

The indicator of child-friendly school was indicated by anti-violence policy during the learning process, which comprised planning, implementation, and evaluation. The learning planning was done by designing an inclusive learning environment without violent behavior, organizing the learning material without neglecting the children's specialties, employing module teaching materials according to the student need and ability, allocating play time and break. The implementation of learning in an inclusion class was conducted by using the following ways: first, a polite greeting within the communication with the students, second, prioritizing psychological approach and positive discipline to educate the students, third, forming study groups in the inclusion class, fourth, so the students could participate together without having discrimination act; utilizing the educative game tool as a therapy for the students with special needs and also playing means, fifth, guiding the students with special needs in an inclusion class when they got through learning difficulties, sixth, raising tolerance to the students with special

and Teachers in Turkey," Child Abuse and Neglect 107, no. January (2020), https://doi.org/10.1016/j.chiabu.2020.104559. 
needs providing break or rest, playtime, and relaxation based on the school schedule. Lastly, the learning evaluation was performed objectively by highlighting authentic assessment. The evaluation was done by not comparing students with each other; the evaluation was based not only on the cognitive aspect but also on student potential and skill.

The author is aware of the limitations of the research related to interview informants, which only involved inclusive class teachers and did not involve regular class teachers, sports teachers, or religious teachers. The data obtained were more representative. Based on this, recommendations for the next researcher are as follows: first, other researchers can focus on how to implement child-friendly schools in inclusive education with a zero bullying system because bullying cases against students with special needs still occur in the community; second, the results of this study are still far from perfect, so further research is needed regarding inclusive schools through childfriendly school programs.

\section{ACKNOWLEDGMENTS}

Sarah Mustika Barokah (State University of Yogyakarta)
Muhammad Nur Wangid (State University of Yogyakarta)

\section{DECLARATION OF CONFLICTING INTERESTS}

The authors declared no potential conflicts of interest with respect to the research, authorship, and/or publication of this article.

\section{FUNDING}

No institution or organization that has provided funding for the research and publication of this article.

\section{ORCID iD}

Sarah Mustika Barokah (iD https://orcid.org/0000-0002-4924-6875

Muhammad Nur Wangid iD https://orcid.org/0000-0003-0348-9238

\section{REFERENCES}

Beattie, Rodrick Babakhanlou \& Tom. "Child Abuse." Innovait, 2019. https://doi.org/10.1001/jama.285.10.1360-JBK0314-3-1. 
Biçakçi, Müdriye Yildiz, Sühendan Er, and Neriman Aral. "An Overview of Child Neglect and Abuse: Types, Causes, Impact and Prevention." Studies on Ethno$\begin{array}{lllll}\text { Medicine } & 10, & & \end{array}$ https://doi.org/10.1080/09735070.2016.11905491.

Chaput, Jean-Philippe, Casey E. Gray, Veronica J. Poitras, Valerie Carson, Reut Gruber, Timothy Olds, Shelly K. Weiss, et al. "Systematic Review Of The Relationships Between Sleep Duration And Health Indicators In School-Aged Children And Youth.” Applied Physiology, Nutrition, and Metabolism 41, no. 6 (Suppl. 3) (June 1, 2016): S266-82. https://doi.org/10.1139/apnm-2015-0627.

Chen, Yi. "Exploring the Role of Communication in Inclusive Education for Children with Learning Disabilities," 296-98. Atlantis Press, 2019. https://www.atlantispress.com/article/125919501.pdf.

Dlamini, Sylvia Lungile, and Davison Makondo. "Effects of Child Abuse on the Academic Performance of Primary School Learners in the Manzini Region, Swaziland." World Journal of Education 7, no. 5 (2017): 58. https://doi.org/10.5430/wje.v7n5p58.

Erhamwilda, Erhamwilda, and Nurul Afrianti. "Analysis on Early Childhood Sexual Abuse and the Implications in Islamic Education." Jurnal Pendidikan Islam 2, no. 1 (2016): 105. https://doi.org/10.15575/jpi.v2i1.696.

Eriyanti, Ribut Wahyu. "Power Gap as One of the Trigger of Verbal Abuses Committed by Teachers in Schools." International Journal of Instruction 11, no. 1 (2018): 363-78. https://doi.org/10.12973/iji.2018.11125a.

Flor, Rezaei Kargar, Kalantar Choreishi Monir, Ajilchi Bita, and Noohi Shahnaz. "Effect of Relaxation Training on Working Memory Capacity and Academic Achievement in Adolescents." Procedia - Social and Behavioral Sciences 82 (2013): 608-13. https://doi.org/10.1016/j.sbspro.2013.06.318.

Friestad-Tate, Jill, Carol Schubert, and Craig McCoy. "Understanding Modular Learning-Developing a Strategic Plan to Embrace Change." Journal on School Educational Technology 9, no. 4 (2014): $32-44$. https://eric.ed.gov/?id=EJ1097629.

Hasibuan, Ahmad Tarmizi, and Rahmawati Rahmawati. "Sekolah Ramah Anak Era Revolusi Industri 4.0 Di SD Muhammadiyah Pajangan 2 Berbah Yogyakarta." AlBidayah: Jurnal Pendidikan Dasar Islam 11, no. 01 (2019): 49-76. https://doi.org/10.14421/al-bidayah.v11i01.180.

Haug, Peder, and Peder Haug. "Understanding Inclusive Education : Ideals and Reality Understanding Inclusive Education : Ideals and Reality." Scandinavian Journal of Disability Research 0, no. 0 (2017): $1-12$. https://doi.org/10.1080/15017419.2016.1224778.

Havighurst, Robert J., Raymond G. Kuhlen, and Carson Mcguire. "Chapter IV: Personality Development." Review of Educational Research 17, no. 5 (1947): 333-44. https://doi.org/10.3102/00346543017005333.

Indraswati, Dyah, Arif Widodo, Aisa Nikmah Rahmatih, Mohammad Archi Maulyda, and Muhammad Erfan. "Implementasi Sekolah Ramah Anak Dan Keluarga Di 
Sdn 2 Hegarsari, Sdn Kaligintung, Dan Sdn 1 Sangkawana.” JKKP (Jurnal Kesejahteraan Keluarga Dan Pendidikan) 7, no. 01 (2020): 51-62. https://doi.org/10.21009/jkkp.071.05.

Kementerian Pemberdayaan Perempuan dan Perlindungan Anak. "Angka Kekerasan Terhadap Anak Tinggi Di Masa Pandemi, Kemen PPPA Sosialisasikan Protokol Perlindungan Anak," 2020. https://www.kemenpppa.go.id/index.php/page/read/29/2738/angka-kekerasanterhadap-anak-tinggi-di-masa-pandemi-kemen-pppa-sosialisasikan-protokolperlindungan-anak.

Kızıltepe, Rukiye, Türkan Y1lmaz Irmak, Duygu Eslek, and Tobias Hecker. "Prevalence of Violence by Teachers and Its Association to Students' Emotional and Behavioral Problems and School Performance: Findings from Secondary School Students and Teachers in Turkey." Child Abuse and Neglect 107, no. January (2020). https://doi.org/10.1016/j.chiabu.2020.104559.

KPAI, Tim. "Miris! Dua Anak Disabilitas Ditelantarkan, Ditolak Sekolah Inklusi Hingga Dikunjungi KPAI," 2020. https:/www.kpai.go.id/berita/miris-dua-anakdisabilitas-ditelantarkan-ditolak-sekolah-inklusi-hingga-dikunjungi-kpai.

Krischler, Mireille, Justin J.W. Powell, and Ineke M. Pit-Ten Cate. "What Is Meant by Inclusion? On the Effects of Different Definitions on Attitudes toward Inclusive Education." European Journal of Special Needs Education 34, no. 5 (2019): 63248. https://doi.org/10.1080/08856257.2019.1580837.

Lai, Emily, Kristen DiCerbo, and Peter Foltz. Skills for Today: What We Know about Teaching and Assessing Collaboration. Pearson. Pearson, 2017. https://eric.ed.gov/?id=ED576950.

Lawson, Monica, Megan H. Piel, and Michaela Simon. "Child Maltreatment during the COVID-19 Pandemic: Consequences of Parental Job Loss on Psychological and Physical Abuse Towards Children." Child Abuse and Neglect, no. July (2020): 104709. https://doi.org/10.1016/j.chiabu.2020.104709.

Leino, Mare. "The Child Friendly School: An Idea Versus Reality." Problems of Education in the 21st Century 29 (2011): 82. http://www.scientiasocialis.lt/pec/files/pdf/vol29/82-88.Leino_Vol.29.pdf.

Lo, June C., Ju Lynn Ong, Ruth L.F. Leong, Joshua J. Gooley, and Michael W.L. Chee. "Cognitive Performance, Sleepiness, and Mood in Partially Sleep Deprived Adolescents: The Need for Sleep Study." Sleep 39, no. 3 (March 1, 2016): 68798. https://doi.org/10.5665/sleep.5552.

Menteri Negara Pemberdayaan Perempuan dan Perlindungan Anak Republik Indonesia. "Peraturan Menteri Negara Pemberdayaan Dan Perlindungan Anak Republik Indonesia Nomor 8 Tahun 2014 Tentang Kebijakan Sekolah Ramah Anak.” Jakarta, Kementerian Negara Pemberdayaan Perempuan dan Perlindungan Anak, 2014.

Minister of National Education Republic of Indonesia. "Regulation of the Minister of National Education of the Republic of Indonesia Number 70 of 2009 Concerning Inclusive Education for Students Who Have Abnormalities and Have Potential 
Intelligence and/or Special Talents." Ministry of National Education Republic of Indonesia, 2009.

Nearchou, Finiki. "Resilience Following Emotional Abuse by Teachers: Insights from a Cross-Sectional Study with Greek Students." Child Abuse and Neglect 78, no. May 2017 (2018): 96-106. https://doi.org/10.1016/j.chiabu.2017.10.012.

People's Consultative Assembly of the Republic of Indonesia. "The 1945 Constitution of the Republic of Indonesia in One Script." Secretariat General of the People's Consultative Assembly of the Republic of Indonesia, 1945.

President of the Republic of Indonesia. "Law of the Republic of Indonesia Number 35 of 2014 Concerning Amendments to Law Number 23 of 2002 Concerning Child Protection." State Secretariat of the Republic of Indonesia, 2014.

Pur, Hamsatu Joseph, Mukhtar Alhaji Liman, and Domiya G. Ali. "Students' Perception of Causes and Effect of Teachers' Psychological Abuse in Senior Secondary Schools in Borno State, Nigeria." Journal of Education and Practice 7, no. 29 (2016): 111-19. https://eric.ed.gov/?id=EJ1118806.Rosada, Admila. "The Effectivity Of Empathic Love Therapy To Increase Subjective Well-Being And Teacher Readiness In Inclusive School." Al-Bidayah: Jurnal Pendidikan Dasar Islam 11, no. 2 (2020): 248-63. https://doi.org/10.14421/al-bidayah.v11i2.282.

Salahuddin, Siddiqui Fakeha. "Building Inclusive Learning Friendly Classrooms: Need of the Hour." International Journal of Reflective Research in Social Sciences 1, no. 1 (2017): 10-13. https://www.reflectivejournals.com/download/4/1-1-4.pdf.

Shinto Thomas, K. Alphonsa Jose, P. Aneesh Kumar. Positive Schooling and Child Development: International Perspectives. Singapore: Springer, 2018. https://doi.org/10.1007/978-981-13-0077-6.

Şimşek, Sinem, and Fulya Cenkseven-Önder. "An Investigation The Behavioral Problems Of Adolescents, Who Perceived Emotional Abuse From Parents And Teachers." Elementary Education Online 10, no. 3 (2011). https://www.academia.edu/download/26115912/v10s3m24.pdf.

State Minister for Child Empowerment and Protection of the Republic of Indonesia. "State Minister for Women's Empowerment and Child Protection of the Republic of Indonesia, "Regulation of the State Minister for Child Empowerment and Protection of the Republic of Indonesia Number 8 of 2014 Concerning Child Friendly School Policies." State Ministry for Child Empowerment and Protection of the Republic of Indonesia, 2014.

Sukiman. Pengembangan Media Pembelajaran. Yogyakarta: Pustaka Insan Madani, 2011.

Sulthon, Sulthon. "Model Pelayanan Pendidikan Inklusi Di Madrasah: Studi Kasus Di Madrasah Ibtidaiyah Ibtidaul Falah Dawe-Kudus." Al-Bidayah: Jurnal Pendidikan Dasar Islam 10, no. 2 (2019): 151-72. https://doi.org/10.14421/albidayah.v10i2.161.

Theoklitou, D., N. Kabitsis, and A. Kabitsi. "Physical and Emotional Abuse of Primary School Children by Teachers." Child Abuse and Neglect 36, no. 1 (2012): 64-70. https://doi.org/10.1016/j.chiabu.2011.05.007. 
Völlinger, Vanessa A., and Marina Supanc. "Student Teachers' Attitudes towards Cooperative Learning in Inclusive Education." European Journal of Psychology of Education 35, no. 3 (2020): 727-49. https://doi.org/10.1007/s10212-01900435-7.

Wang, Wen-ling, and Chang-yuan Kuo. "Relationships Among Teachers ' Positive Discipline, Students 'Well-Being and Teachers' Effective Teaching : A Study of Special Education Teachers and Adolescent Students With Learning Disabilities in Taiwan Relationships Among Teachers ' Positive Disci." International Journal of Disability, Development and Education, 2018, 1-17. https://doi.org/10.1080/1034912X.2018.1441978.

Yeo, Sing Chen, Jacinda Tan, June C. Lo, Michael W.L. Chee, and Joshua J. Gooley. "Associations of Time Spent on Homework or Studying with Nocturnal Sleep Behavior and Depression Symptoms in Adolescents from Singapore." Sleep Health 6, no. 6 (2020): 758-66. https://doi.org/10.1016/j.sleh.2020.04.011. 
This page is intentionally left blank 